\title{
Promising without Speaking: Military Realignment and Political Promising in Japan
}

Chad Nilep

\section{Introduction}

US Marine Corps Air Station Futenma, an American military base in Okinawa, Japan, has long been unpopular with local residents. This chapter discusses a plan to relocate the base, and focuses particularly on charges that former Japanese Prime Minister Yukio Hatoyama failed to deliver on a promise to remove the base from Okinawa prefecture in 2010. Data come primarily from news coverage and editorials during Hatoyama's election campaign and administration. I will argue that the promise of action came not from any particular speech by Mr. Hatoyama, but was an interdiscursive achievement involving Hatoyama, members of his cabinet, the main opposition party, and the Japanese news media. I discuss the concept of a metaphorical promise, an expectation of future action created not through any specific speech act but through complexes of social interaction.

In 1945, during the Second World War, US Army and Marine divisions launched an attack on Okinawa and the Ryukyu islands in the south of Japan. The plan was to seize the islands in order to build a forward base from which to attack the main islands of the Japanese archipelago. Anticipating such an attack, the Japanese military had fortified Okinawa and the surrounding area, conscripting some 20,000 local men and boys in the process (Fisch 1987). In fierce fighting from April to June 1945, the US forces defeated the Japanese troops defending the islands. A US Marine Corpss estimate suggests that more than 107,000 Japanese fighters were killed during the battle, while US losses included 38,000 killed, wounded, or missing in action, plus an additional 26,000 non-combat casualties (Nichols and Shaw 1955).

Following the Battle of Okinawa, the United States Army established an administration to govern the islands while building bases from which to continue the war (Fisch 1987). In August of 1945, following the atomic bombings of Hiroshima and Nagasaki, Japan surrendered to the Allied Forces, ending the fighting. Japan was occupied by American and British Commonwealth forces from 1945 to 1952, during which time control of Okinawa and the surrounding Ryukyu islands was shifted from the Army to a US civil administration. In practice, however, policies and programs of the military and civilian administrations were largely unchanged (Fisch 1987). The Japanese Constitution, accepted in 1947, renounced war and committed the nation not to establish military forces. ${ }^{1}$ US forces in Okinawa therefore continued to build bases to serve in place of Japanese forces. With the start of the Cold War and the establishment of a communist government in China, Okinawa's proximity to US interests in the Philippines, Taiwan, and Guam also made it a valuable staging ground for American forces (Fisch 1987).

Under the 1952 peace treaty that formally ended the war, administrative control of Okinawa was ceded to the United States (Treaty of Peace with Japan 1952). The islands were administered by the United States from 1952 until 1972, when they

\footnotetext{
Japan today has a de facto military called the Self Defence Forces. The United States nonetheless commits to defend Japan against military attack under treaty and status of forces agreements (Treaty of Mutual Cooperation and Security 1960).
}

Nilep, Chad. 2013. "Promising without Speaking: Military Realignment and Political Promising in Japan." In Discourses of War and Peace, Adam Hodges (ed.). Oxford:

Oxford University Press. 
were returned to Japanese control. During this time dozens of Marine, Air Force, Navy, and Army bases were established in the islands that now comprise Okinawa Prefecture, and many remain there even after the islands' return to Japan.

While many Japanese people favor the presence of US troops, which are thought to deter aggression from neighboring states, the majority in Okinawa are less sanguine. Although Okinawa comprises less than one percent of Japan's land area, it hosts nearly $75 \%$ of US military installations in the country (Ministry of Defense 2006). The large military presence creates noise, land use conflicts, and safety issues, including occasional military accidents and frequent traffic incidents. US Marine Corps Air Station Futenma, an installation of more than 1,200 acres (500 hectares) in the middle of the city of Ginowan, has been a particular focus for Okinawans uneasy with the US military presence (Inoue 2007). Futenma came under increased criticism in 1995 when a twelve-year-old girl was abducted and raped by US Marines stationed there (Economist 2010). In 1996 Tokyo and Washington began negotiations to remove Air Station Futenma from Ginowan and to return the land and facilities to Japanese control (Inoue 2007).

Today, more than a decade after the start of negotiations and five years after Tokyo and Washington agreed on a realignment plan, Air Station Futenma remains in Ginowan. The 2006 realignment plan called for the Marines at Futenma to be split between locations in Guam and elsewhere in Okinawa. Press coverage in 2009 and 2010 suggested that then-prime minister Yukio Hatoyama had promised to remove the Marines from Okinawa entirely, a promise that he failed to deliver. Yet there is no single moment, no clear speech in which Hatoyama commits himself and his government to such a course of action. Instead, the "promise" evolved over the course of several months in the words of many individuals. This chapter explores the genesis of that promise and the interpersonal nature of political promising, as well as ideologies of political promising as an individual speech act. It suggests that, as peace is not merely the absence of war, political accord is not merely the the absence of discordant speech.

\section{Political promising}

In "Read My Article," Jane Hill (2001) undertakes an investigation of political promising in the United States by investigating a speech by candidate George H.W. Bush during the 1988 Republican National Convention. In his speech, Bush predicted, "The Congress will push me to raise taxes [...] and I'll say to them, 'Read my lips: No new taxes"' (qtd in Hill 2001). When President Bush accepted a 1990 budget that included new taxes as well as an increase in rates, newspapers and other commentators accused him of breaking a promise. Members of Bush's White House staff and former campaign staff insisted, on the contrary, that the "Read My Lips" line was not intended as a promise of action but as an expression of leadership style. Bush would go on to lose his 1992 bid for re-election, a loss partially attributed to loss of trust among voters.

Hill (2001) notes that American political speech must fulfill at least two functions, and thus it is judged against two different metrics. First, a politician must give his or her "word," specific information about planned actions and goals. Hill calls this the discourse of truth since the speaker is bound by Grice's (1975) maxim of quality to say only what they believe to be true and not what they believe to be false. If this "word" is seen as false, the politician may be held unworthy of election. At the same time, though, the politician is judged in terms of leadership and thus must speak 
with an eye toward what Hill calls the discourse of theater. In addition to his or her "word," the politician must express a "message," a set of positive emotional themes that draw voters to the candidate or leader. "Message" is expressed through theatrical cues such as images of the politician and music or colors associated with a campaign, and must also be reflected in the candidate's way of speaking.

In the case of George H.W. Bush, the line "Read my lips: No new taxes" was intended, according to Bush's aides, as an expression of message. In poetic terms, it has two spondee triplets, sets of three stressed syllables, making it highly rhythmic. Its use of reported speech - the candidate's own speech in an imagined future - makes it highly personal. And the words "read my lips" were variously attributed to actor Clint Eastwood (Hill 2001) or various rock and roll musicians (Safire 1988), making it highly masculine.

At the same time, however, the line can be understood not simply as an abstract expression of "message" but also as a specific instance of "word." Since it purports to quote a future utterance by Mr. Bush, it commits him to utter these words or at least to hold to the notion they seem to express. It can be heard as a commissive speech act (Searle 1975, 1980), a promise of future action, and indeed was widely interpreted as such.

Although John Searle (1980) suggests that commissives - promises of future action - are a central speech act in human interaction, research in various settings, especially Michelle Rosaldo's (1982) study of Ilongot speech in the Philippines, shows that the particular speech acts that are held to be central vary from one setting to the next. Hill (2001) recognizes that judgment in terms of truth and theater are aspects of American political speech, and that local linguistic ideologies determine how acts of speech are evaluated. It is within a "regime of personalism" in the United States that the utterances of a politician can be taken as both expressions of personal leadership ability and commitments to future action.

The study which forms the data for this chapter initially set out to investigate certain promises attributed to Japanese Prime Minister Yukio Hatoyama in order to see whether the discourse of truth and the discourse of theater that Hill identifies in US political rhetoric are equally at play in Japan.

In August 2009 Hatoyama became prime minister when his Democratic Party of Japan (DPJ) took control of the Diet, the Japanese parliament, by winning a landslide election victory over the long-time ruling party, the Liberal Democratic Party (LDP). Shortly after the Hatoyama government was formed in September 2009, a public opinion survey found a $72 \%$ approval rate among respondents. By the spring of 2010, however, that approval rating had fallen to around $20 \%$ and newspaper editorials, opposition politicians, and even some former coalition partners were calling for Hatoyama's resignation (Japan Times 2010, May 5).

Press coverage cited two causes for the sudden fall in the government's popularity: a financial scandal and a broken promise. The financial scandal involved allegedly improper contributions to Hatoyama's campaign and to that of former DPJ president Ichiro Ozawa. Ozawa would eventually be indicted over his alleged improprieties. More curious, though, is the charge of false promises.

According to news coverage as well as newspaper editorials, Hatoyama had failed to deliver on his campaign promise to remove US Marine Corps Air Station Futenma from Okinawa. What makes this charge curious is not Hatoyama's failure to remove the base - he handled the issue clumsily, and the base is still where it was 
before his election. Rather, the curiosity comes from the fact that Hatoyama did not mention the base during his campaign. Indeed, an editorial in the International Herald Tribune Asahi newspaper before the election lamented the fact that the DPJ made no promises about the base (IHT/Asahi 2009, July 27). Yet by the following spring the same newspaper was among those charging that Hatoyama "failed... on his promise to move the facility 'at least' out of the prefecture" (IHT/Asahi 2010, May 15).

During the 2009 campaign, the Democratic Party of Japan's election platform made only vague allusions to a possible re-examination of US forces in Japan, and did not mention the Futenma station by name. Instead, an expectation that arose both during the campaign and after the election was cast in retrospect as a campaign promise, despite a general lack of clear statements on the issue during the campaign. With this in mind, I analyzed a corpus of newspaper articles and editorials to trace how this "promise" came to be jointly constructed by the news media, Hatoyama, members of his cabinet, and partners in the coalition government.

The discourses analyzed here reveal ideologies within contemporary Japanese politics that locate responsibility for truth and leadership in particular individuals. This cluster of ideologies is similar to that described by Hill (2001) among Americans, and make political speech similarly "dangerous" in Japan and the United States. In addition, the analysis illustrates how discourses of promising and leading do not issue solely from the individuals held responsible for them. Interlocutors and interpreters contribute to the discourses which they then attribute to political leaders.

\section{Metaphorical promising}

In everyday language, the noun promise is used in multiple senses, at least two of which are relevant to the discussion here. In one sense, a promise is a linguistic act in which one person expresses a commitment to undertake some activity in the future. In a prototypical promise of this sense a speaker may say, for example, "I promise to pay you twenty dollars tomorrow." By saying these words the speaker commits to pay twenty dollars to the listener the following day. In the philosophy of language this type of speech, along with its required preconditions and its ensuing commitment, is known as a commissive speech act. Searle defines commissive speech acts as, "those illocutionary acts whose point is to commit the speaker... to some future course of action" (1975: 356).

A second sense of the noun promise in everyday language relates not to an act of speaking but to an expectation of future performance. For example, an athlete, a new employee, or a young scholar may be said to "show great promise." A promising scholar does not actually commit herself to particular actions in the future through acts of speaking. Instead, aspects of the scholar's behavior, such as asking insightful questions or writing well, as well as aspects of the scholar's social positioning, such as relationships with prominent teachers or acceptance at prestigious institutions cause observers to expect future academic or professional success. Unlike a commissive speech act, "showing promise" in this sense does not require sincerity or commitment on the part of the promiser. Still, if the expectations of future success are not met - if, for example, the young scholar does not go on to produce interesting work in her field of study - one may speak of unfulfilled promise.

What both of these ideas have in common is an orientation toward future actions or states. As the speaker who makes a promise commits to some future action, the hearers expect this action to be fulfilled at the appropriate time. When observers label an athlete, scholar, or the like as "showing promise" they expect some positive 
performance in the future (though neither the nature nor the time of the performance need be precisely specified). Talk of promise in both senses therefore relates to expectations about the future.

In the case described below, expectations about the future are built from a combination of discourse and social positioning. Between 1998 and 2009 the Democratic Party of Japan was a major opposition party in Japan's parliament, while the Liberal Democratic Party held parliamentary majority and the position of prime minister. With the election of a DPJ majority in 2009, then, came an expectation that certain government policies would change. These expectations included both specific programs that the party outlined in its election manifesto and general ideas about change and reform that grew simply from the fact that a new party had come to power. As president of the Democratic Party of Japan, Yukio Hatoyama both made promises - he uttered certain locutions that committed him to specific actions - and showed promise; he raised expectations simply by virtue of being the leader of the former opposition party.

Hill (2001) notes that locating responsibility for a promise in a single speaker is part of an American linguistic ideology that she labels the regime of personalism, building on observations by Alessandro Duranti (1993). The truth and meaning of a discourse may be distributed across the range of individuals involved in the discourse's production and uptake, yet traditionally we hold a single individual responsible for the discourse. In the case of a promise, we identify a single promiser and hold this individual responsible if expectations, which are jointly constructed and held, are not met.

In the case that follows, there is no single locutionary act, no utterance in which Hatoyama commits himself to remove the US Marines from Okinawa. Expectations for action, and the ability to act, are widely distributed among participants. Furthermore, these expectations develop not only from linguistic action but also from social positioning. The promise at the center of the events, then, resembles a commissive speech act in some respects, and is held to have the effect of such an illocution, even though it has neither the linguistic form nor the distribution of speaker/listener roles of a typical promise. It is instead a metaphorical promise, in the sense that it is regarded as a promise despite the crucial absence of an act of speaking.

\section{The data}

Data for this study come primarily from four English-medium news sources published in Japan. Kyodo News is a cooperative news agency that distributes stories from its own reporters and from member newspapers and broadcasters in Japanese, English, and Chinese throughout Japan and overseas. Daily Yomiuri is the English-language publication of Yomiuri Shimbun, a center-right broadsheet that is the largest daily newspaper in Japan. International Herald Tribune Asahi (hereafter IHT/Asahi) is published by Asahi Shimbun, Japan's second-largest newspaper, in collaboration with the International Herald Tribune, an affiliate of The New York Times. The Japan Times, a centrist broadsheet published exclusively in English, has a smaller circulation than the other sources.

The newspaper articles and editorials analyzed in this chapter were gathered using both the Factiva and Proquest newspaper archives. Stories published between June 2009 and June 2010 mentioning the Democratic Party of Japan, Yukio 
Hatoyama, or the US Marine Corps Air Station Futenma were collected. Removing duplicates and minor updates yielded a corpus of approximately 450 pieces, each of which was read and analyzed using qualitative methods of discourse analysis. This corpus of Japanese news stories was supplemented with documents referenced or alluded to in editorials or reportage in the corpus. Two manifestos, published by the Democratic Party of Japan and the Liberal Democratic Party prior to the August 2009 general election, describe each party's platform for governance (DPJ 2009; LDP 2009). In addition, the "United States-Japan Roadmap for Realignment Implementation," the text of a 2006 agreement between Japan and the United States to remove Marines from Marine Corps Air Station Futenma to Guam and other parts of Okinawa, was published by Japan's Ministry of Foreign Affairs on its public web site (MOFA 2006). Finally, a guest editorial by Yukio Hatoyama published in the New York Times on 26 August 2009 was also included in the corpus (Hatoyama 2009). In addition to these corpus materials a third election manifesto, that of the DPJ's coalition partner Social Democratic Party, was subsequently consulted (SDP 2009).

\section{Government in Japan}

Japan is a constitutional monarchy. The Emperor of Japan is the nominal head of state, but he holds essentially no executive or legislative power. Government is via a parliamentary system comprising two houses, collectively known as the Kokkai or Diet. The members of each house are elected by Japan's citizens through a combination of direct election of individual members and proportional election via political parties. Legislation is introduced and voted in the lower House of Representatives. If a bill passes the lower house, it moves on to the upper House of Councilors. If the upper house rejects a bill, it may still become law if it receives support from a two-thirds super-majority in a second vote in the lower house.

The prime minister, elected from the lower House of Representatives by a vote of both houses, serves as the executive head of government. The prime minister in turn selects a cabinet, whose members may come from either the lower or the upper house. Elections for the lower house are held every four years, or following a vote of no-confidence by its members. Members of the upper house serve six year terms, with elections for approximately half of the members every three years.

Parallel to the cabinet is a strong bureaucratic system. The prime minister appoints Ministers of State responsible for foreign affairs, justice, defense, education, and ten other specific functions. Each ministry also features a Senior Vice Minister, the highest ranking civil servant in the ministry's bureaucracy. Given the short terms in office of most cabinet ministers (often one to two years), these senior bureaucrats traditionally have both managed the ministries' professional civil servants and also led policy direction, with political cabinet ministers simply accepting or rejecting decisions of the Senior Vice Minister (Neary 2004). This arrangement began to change under the government of Prime Minister Junichiro Koizumi from 2001 to 2006 (Estévez-Abe 2006, Neary 2004), a shift which continued under Prime Minister Hatoyama.

Compared to Great Britain or other Westminster-style parliaments, the Japanese Diet features a relatively weak party system. Individual members of parliament tend to owe loyalty not to the party itself but to other individual politicians. Parties tend to be divided into habatsu or factions, each loyal to one powerful leader (Estevez-Abe 2006). Prior to the government of Prime Minister 
Koizumi, cabinet members were often chosen in a manner to maximize the number of factions represented in the cabinet (Neary 2004).

Before becoming party leader Yukio Hatoyama was associated with a faction in the DPJ loyal to Ichiro Ozawa, who led the party immediately prior to Hatoyama. This association would seem to have an important effect on Hatoyama's own government for two reasons. First, Ozawa's alleged fund raising improprieties, which led to his resignation as party leader, were cited as one reason for Hatoyama's falling poll numbers in early 2010 (Kin 2009). Moreover, unlike Hatoyama, Ozawa actually had expressed a desire to reduce the presence of US forces in Japan early in 2009, several months before Hatoyama became party leader (Furukawa, Murao, and Kuromi 2009). Although one might expect that this fact influenced expectations for Hatoyama's own position on base realignment, news sources in the corpus do not mention Ozawa in regard to the Futenma controversy after August 2009. For that reason, fuller exploration of Ozawa's role in the issue is beyond the scope of this analysis.

Japan's lower house of parliament as well as the cabinet was controlled by the Liberal Democratic Party (LDP) or by coalitions including the LDP almost continuously from 1955 until 2009, with the exception of a coalition government of smaller parties that ruled for eleven months during 1993-94. Since 2006, though, popular discontent with the long-time ruling party had been growing in Japan, and three governments in a row had lasted no more than one year each (see Table 1). The DPJ swept to power promising to end corruption in the national government, increase direct benefits to individuals, and devolve more power to local governments (DPJ 2009).

Table 1. Japan's recent prime ministers

\begin{tabular}{lll}
\hline Prime Minister & Political party & Dates in office \\
\hline Junichiro Koizumi & Liberal Democratic Party (LDP) & April 2001-Sept. 2006 \\
Shinzō Abe & LDP & Sept. 2006-Sept. 2007 \\
Yasuo Fukuda & LDP & Sept. 2007-Sept. 2008 \\
Taro Aso & LDP & Sept. 2008-Sept. 2009 \\
Yukio Hatoyama & Democratic Party of Japan (DPJ) & Sept. 2009-June 2010 \\
Naoto Kan & DPJ & June 2010-Sept. 2011 \\
Yoshihiko Noda & DPJ & Sept. 20011-Dec. 2012 \\
\hline
\end{tabular}

The government of LDP Prime Minister Junichiro Koizumi from 2001 to 2006 was generally regarded as successful, and Koizumi himself was quite popular. Koizumi was one of the first leaders to take advantage of changes in Japanese election laws and party rules that allowed for greater concentration of power in the office of prime minister (Estévez-Abe 2006). He was a highly visible party leader who led his party to a substantial electoral victory in 2005 and used his strong majority to push through fiscally conservative policies, including privatization of the postal service. Following Koizumi's retirement as prime minister and party leader, however, the next three LDP prime ministers held the office for only one year each. Shinzō Abe resigned in 2007 amid opposition criticism involving funding scandals; Yasuo Fukuda was censured by the opposition-controlled upper house in 2008 and resigned thereafter; 
and Taro Aso left the party's leadership in 2009 when the DPJ soundly defeated the LDP in the general election.

In the Democratic Party of Japan's manifesto, its platform for the 2009 elections, party president Yukio Hatoyama promised that if elected his government would rule by five principles. The first three principles - politician-led government, cabinet-centered policy making, and leadership from the Prime Minister's Office were reminiscent of Koizumi's ruling style. Principle 4, "From a vertically organized society of vested interests to a horizontal society bound by human ties," appeared to be an expression of greater social progressivism, and the details of the manifesto called for increased social spending on childcare allowances, free public high schools, and reform of the pension and medical care systems. Under the heading of Principle 5, "From centralized government to regional sovereignty," the manifesto promised to give greater decision-making authority to local governments.

\section{Emergence of the promise}

In 2005 and 2006, negotiators from the United States and Japan developed a plan to "realign" US military installations in Okinawa Prefecture in order to remove US Marine Corps Air Station Futenma while reconstituting many of the base's functions elsewhere in Okinawa and in Guam. On 1 May 2006 US Secretary of State Condoleeza Rice, Secretary of Defense Donald Rumsfeld, Japanese Minister of Foreign Affairs Taro Aso, and Minister of State for Defense Fukushiro Nukaga signed the "United States-Japan Roadmap for Realignment Implementation" (MOFA 2006). The Aso-Rice agreement called for the two countries to build a new air station off the coast of Henoko, Okinawa, near the existing US Camp Schwab base by 2014. Approximately 8,000 US Marines and 9,000 dependents would then be removed from Japan to Guam, other Marines moved to the new air station, and Futenma and other facilities returned to Japanese control.

The Aso-Rice agreement was controversial within Okinawa. Although it would remove the Futenma base from the city of Ginowan, the off-shore replacement facility would still be within Okinawa prefecture, and its construction would destroy a coral reef and threaten the habitat of a protected marine mammal (Economist 2010). The plan was nonetheless acceptable in Tokyo and in Washington, and subsequent governments - including three short-lived LDP governments in Japan - made no moves to change it.

The Democratic Party of Japan made little mention of the controversial AsoRice agreement during the summer of 2009, amid preparations for an expected general election. One of the few mentions of US forces in Okinawa in the Diet that summer was a statement by Taro Aso. The former minister of foreign affairs was by this time serving as prime minister. During a debate in June with DPJ president Hatoyama, Aso criticized a past suggestion from the former DPJ president, Ichiro Ozawa, that most US forces should be removed from Japan. Coverage of the debate in Daily Yomiuri suggested that Aso "dredged up a past remark" by Hatoyama's predecessor because he was losing the debate (Furukawa, Murao and Kuromi 2009). For the press and much of the public, the status of US forces was not a central concern that summer.

Okinawa and the status of US military forces was not a major issue for the DPJ, either. It became an issue only when the DPJ began discussion with another opposition party, the Social Democratic Party, about the possibility of forming a coalition government if elected. The SDP is to the political left of the DPJ, and is 
avowedly pacifist. Under the heading "Peace and human rights" the SDP election manifesto made the following commitment.

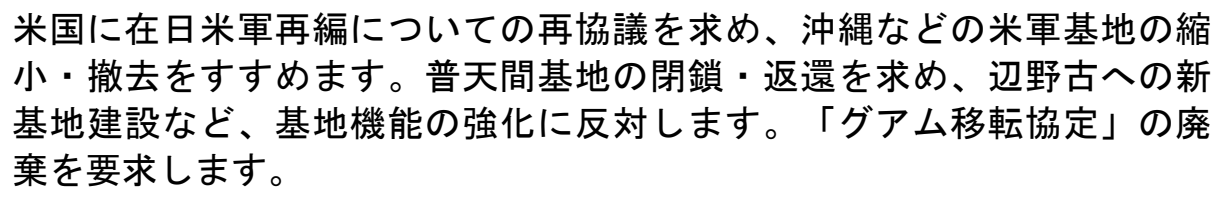

Request new consultations with the United States on the realignment of US forces in Japan, and hasten the reduction/removal of US bases from Okinawa and elsewhere. Seek to hasten the closure/return [to Japan] of the Futenma base, and oppose the construction of a new base at Henoko or the expansion of [existing] bases. Demand repeal of the "Guam transfer agreement." (SDP 2009, my translation)

Unlike the DPJ, which avoided strong statements on the issue, the SDP committed itself not only to support the removal of Air Station Futenma but also to oppose its replacement with the new facilities called for in what it labels the "Guam transfer agreement," the 2006 Aso-Rice agreement.

SDP leader Mizuho Fukushima initially resisted working with the DPJ since it refused to take positions on the US military in Japan or Japan's support of US and British naval operations in the Indian Ocean. Eventually, however, SDP joined DPJ and a third minor party, the centrist People's New Party, in embracing five pledges to be made in each party's manifesto in anticipation of forming a coalition government (Daily Yomiuri 2009, June 13). The five pledges related to domestic economic issues, and not to military or foreign affairs.

Throughout July of 2009 Hatoyama spoke out on domestic issues. His major goal if elected would be to reform the relationship between the cabinet and government bureaucracies. Under the Koizumi administration the office of prime minister had begun to take the lead in setting government policy, minimizing the role of civil service senior vice ministers (Estévez-Abe 2006). Hatoyama vowed to take power away from the bureaucracies and to give it not solely to the prime minister but to each of the cabinet's Ministers of State (Harris and Murphy 2009).

In addition to restructuring the relationship between the cabinet and the bureaucracy, Hatoyama and the DPJ campaigned on economic issues. At a "next cabinet" meeting in July, they pledged to make high schools tuition free, establish a child care allowance, establish supports for agriculture, and cut several provisional taxes (Daily Yomiuri 2009, July 17). Hatoyama avoided making any promises to change Japan's diplomatic or military positions. In response to a formal request from the SDP to help craft legislation banning nuclear weapons, he expressed concern over possible threats from North Korea and said that he would need to consult with the USA before taking any action (Kyodo 2009, July 24).

The Democratic Party of Japan officially released its manifesto for the upcoming election on 18 July 2009, though versions had been leaked to the press some weeks earlier. The manifesto made no explicit mention of Marine Corps Air Station Futenma. Near the end of the document, however, was a brief mention of the realignment agreement. Point 51 of the manifesto's 55 pledges is headed "Build a close and equal Japan-U.S. relationship." As with the rest of the document, this pledge is largely economic, suggesting that the two countries should conclude a free trade 
agreement while being careful not to harm Japan's agricultural industry. The section's last paragraph discusses US forces and base realignment.

\section{日米地位協定の改定を提起し、米軍再編や在日米軍基地のあり方について も見直しの方向で臨む。}

Propose the revision of the Japan-U.S. Status of Forces Agreement; move in the direction of re-examining the realignment of the U.S. military forces in Japan and the role of U.S. military bases in Japan. (DPJ 2009, official DPJ translation)

This is hardly a clear commitment. It suggests only the possibility of revisiting the Status of Forces Agreement, not a commitment to change that agreement or the AsoRice plan in specific ways. In what appears to be a criticism of the DPJ's lack of clarity on this issue, the Liberal Democratic Party's manifesto suggested, "We cannot entrust the safety of Japan to a political party... that cannot even reach agreement among its members about their stance on these [military and diplomatic] issues" (LDP 2009). ${ }^{2}$

On 26 August 2009, a guest editorial by Yukio Hatoyama was published in The New York Times. In it, he criticized globalization as a form of neo-liberal capitalism centered on US interests, and called for "fraternity - as in the French slogan 'liberté, égalité, fraternité' - as a force for moderating the danger" (Hatoyama 2009). An editorial in The Japan Times read Hatoyama's criticism of the United States as a signal that he would try to move the Futenma replacement site outside of Japan (Japan Times 2009, September 6). But Hatoyama's editorial contained no mention of the realignment plan. His comments on military issues were limited to an offhand criticism of the war in Iraq and an allowance that the US "will remain the world's leading military and economic power for the next two to three decades" (Hatoyama 2009). The bulk of his criticism related to economic and political philosophy.

The Democratic Party of Japan won the election on 30 August and took enough seats to form a government. The DPJ introduced a coalition government on 9 September with leaders of the People's New Party and the Social Democratic Party in minor cabinet positions. An 11 September report in The Japan Times suggested that the Futenma realignment had been a sticking point in negotiating the coalition. The SDP reportedly demanded that the new government renegotiate the agreement with the US, while the DPJ resisted, not wanting to show any disagreement with the US ahead of a scheduled visit to Japan from President Barack Obama. In the end the parties agreed to "propose revising the SOFA and take a stance toward reviewing the realignment plans" (Japan Times 2009, September 11).

Prime Minister Hatoyama and US President Obama met for the first time on 23 September. They agreed to work together to face North Korea and to combat global warming, but did not discuss any contentious issues (Japan Times 2009, September 25). An editorial in the conservative Daily Yomiuri urged the DPJ to stick to the 2006 Aso-Rice agreement, saying that this would be the fastest route to removing US Marines from Ginowan (Daily Yomiuri 2009, September 24).

2 The LDP manifesto was released on 12 August 2009, six days before the DPJ manifesto. It therefore cannot be reacting specifically to language in the final document. Nonetheless, the criticism clearly appears to be directed at the DPJ position. The LDP manifesto does not mention US forces or base realignment. 
Over the next two weeks conflicting ideas about how to deal with Air Station Futenma were announced from various cabinet offices. The State Minister for Okinawa, Seiji Maehara, suggested that the government may revisit the Aso-Rice agreement (Kyodo 2009, October 3a), but Defense Minister Toshimi Kitazawa said that it would be difficult to find any other solution (Kyodo 2009, October 2). At a press conference in Cambodia, Foreign Minister Katsuya Okada said that he planned to renegotiate the base realignment deal with the US in exchange for a promise that Japan would continue refueling ships in support of the war in Afghanistan (Kyodo 2009, October 3b).

On 7 October Prime Minister Hatoyama held a press conference to address the conflicting statements from cabinet ministers. He reportedly met with the mayor of Ginowan and the governor of Okinawa, each of whom seemed prepared to accept realignment as described in the Aso-Rice agreement. At his press conference Hatoyama referred to the manifesto's pledge to "move in the direction of reexamining realignment." He suggested that the manifesto may be regarded as a promise, but at the same time intimated that the re-examination process may not be a timely one.

\section{国民との約束事だから基本的にそれを守ることが大事だ。簡単に変える ベきではない。[しかし]時間という要素によって変化する可能性は否定 しない。(qtd in Okinawa Times 2009)}

What we stated in our manifesto is certainly one promise we have made, and I still don't think we should change that so easily. [But] I would not deny the possibility that it could change in terms of time. (qtd in Kyodo 2009, October 7)

In framing the manifesto's decidedly weak language as 約束事 yakusokugoto - a promise or arrangement - Hatoyama appears to strengthen the illocutionary force of the manifesto somewhat. At the same time, however, he weakens the suggestion that change will happen in the near future. Furthermore, there is no clarification of what that change might be or when it may arrive. Hatoyama offers no clear vision for government action at any definite time in the future.

The following day Daily Yomiuri published an editorial by Riichiro Maeki, deputy political news editor of Yomiuri Shimbun. ${ }^{3}$ Maeki called on the DPJ "to review their electoral promises" (Maeki 2009). After criticizing the government's handling of a separate health care system for the elderly and its abandoning of LDP plans to build a dam, he writes, "In its general election manifesto, the DPJ stated that the realignment plans of U.S. forces in Japan 'must be reviewed," a review that Maeki suggests would be a mistake (Maeki 2009). Despite the quotation marks in Maeki's prose, however, the words "must be reviewed" do not appear in the DPJ manifesto. The party's own official English translation only called for a "move in the direction of re-examining." Likewise the original Japanese text contained nothing suggesting strong obligation.

3 Maeki's editorial, written in Japanese and translated into English, was undoubtedly prepared before Hatoyama delivered his remarks in Okinawa. 
Concerning the realignment of US military forces or how US military bases in Japan ought to be, look toward reviewing the course of action. (DPJ 2009, my translation)

Maeki calls on the DPJ to be flexible in dealing with these issues. Given the diversity of suggestions emanating from the cabinet, however, obstinacy on the issue of base realignment does not seem to be the problem.

From 26 October to 30 November, the parliament convened in extraordinary session. In light of the United States congress's recent voted to accept the 2006 AsoRice agreement on Futenma relocation and President Obama's planned visit to Japan in November, editorials in all three newspapers in the corpus called for the government to conclude its review of the relocation plan quickly (Daily Yomiuri 2009, October 14; Japan Times 2009, October 23; IHT/Asahi 2009, October 27). The conservative Daily Yomiuri was especially insistent on this point, publishing editorials on November 3, 7, 14, and 18 calling on Hatoyama to accept the 2006 agreement. When the parliamentary session ended with no conclusion on the issue, the paper accused Hatoyama of sacrificing Japan's relationship with the United States in order to keep the Social Democrats in the government (Daily Yomiuri 2009, December 4). An editorial in IHT/Asahi was less alarmist, suggesting that the US-Japan relationship could weather disagreement on this issue, but warning that if Hatoyama could not make a decision in spite of his coalition partners' intransigence, there would be no political progress before the next general election (IHT/Asahi 2009, December 5).

In December Hatoyama announced that he would not make any decision on the Futenma relocation issue before the end of the year. US Secretary of State Hillary Clinton visited Japan's ambassador in Washington to urge implementation of the AsoRice agreement (Japan Times 2009, December 24). Public approval for the Hatoyama government fell from around $70 \%$ after the election to less than $50 \%$ in December, with many respondents expressing displeasure with the prime minister's lack of leadership (IHT/Asahi 2009, December 23).

In January Foreign Minister Katsuya Okada attended a summit meeting in Hawaii with Secretary Clinton in an attempt to shore up relations between the two nations (IHT/Asahi 2010, January 11; Daily Yomiuri 2010, January 14). In a speech before parliament Prime Minister Hatoyama announced, "The government shall decide on a specific [Futenma] replacement site by the end of May" (Kyodo 2010, January 30). Local elections in Okinawa by that time had made acceptance of the Aso-Rice agreement more difficult, however. For the first time a mayor had been elected in Nago, the city near the proposed replacement site, who opposed building the new facility. A resolution had also passed in the Okinawa assembly opposing the 2006 agreement. With growing opposition to the current plan and no specific alternative on the table, editorials in each of the newspapers in the corpus criticized Hatoyama's lack of leadership (IHT/Asahi 2010, January 26; Japan Times 2010, January 27; Daily Yomiuri 2010, January 30).

Unlike earlier statements in the party manifesto and Hatoyama's addresses to parliament during the extraordinary session, his declaration that "the government shall decide on a specific replacement site by the end of May" was a clear and specific commitment to a future course of action. By April newspaper editorials were referring to Hatoyama's “promises" (IHT/Asahi 2010, March 6; Daily Yomiuri 2010, April 15; Japan Times 2010, April 24). 
Public opinion surveys in May found that approval for the DPJ-led government had fallen to around 20\%. Of those dissatisfied, $40 \%$ cited a lack of leadership and 19\% a lack of trust (Japan Times 2010, May 5). In newspaper editorials the lack of trust came in for particular criticism. On 6 May Hatoyama insisted to reporters that his party's manifesto never promised to remove the Futenma replacement facility outside of Okinawa. In making this argument he explained, "Moving it at the very least outside the prefecture merely represented my own thinking" (Asahi.com 2010). Editorials, however, seized upon the words "at least outside the prefecture," and cast this not as an excuse offered in May but as a promise made the previous August. IHT/Asahi wrote, "Prime Minister Yukio Hatoyama pledged during an election campaign to relocate the U.S. Marine Corpss Air Station Futenma outside Okinawa Prefecture" (2010, May 7). The Japan Times wrote, "Before the Aug. 30 Lower House election last year, Mr. Yukio Hatoyama... made a campaign pledge to move U.S. Marine Corpss Air Station Futenma, Okinawa, outside Okinawa or even abroad" (2010, May 7). While he made vague allusions to the base realignment plan during the campaign, however, Hatoyama had refrained from explicitly making any such promise.

On 13 May the DPJ released its revised base realignment plan. Contrary to expectations, it was substantially similar to the 2006 Aso-Rice plan, with several minor modifications. The replacement facility would still be built at Henoko in Okinawa, but instead of a V-shaped pair of runways on reclaimed land, it would feature a single runway on pilings. Hatoyama seemed to feel that he had delivered on his promise to announce a new plan by the end of May. The Daily Yomiuri, though, called the new plan a "hopeless hodge-podge" (2010, May 14), while IHT/Asahi declared Hatoyama "has effectively reneged on his promise" (2010, May 15).

Table 2. Timeline of key events

\begin{tabular}{|l|l|}
\hline Date & Event \\
\hline 1879 & Japan annexes Okinawa prefecture. \\
\hline April-June 1945 & Battle of Okinawa; US military seizes Okinawa. \\
\hline May 1947 & Japan adopts a constitution renouncing the right to wage war. \\
\hline April 1952 & Japan signs the Treaty of Peace officially ending World War II. \\
\hline $1952-1972$ & US Civil Administration controls Okinawa and the Ryukyu Islands. \\
\hline January 1960 & US/Japan sign "Treaty of mutual cooperation and security." \\
\hline May 1972 & Okinawa prefecture returns to Japanese control. US bases remain. \\
\hline September 1995 & Two Marines and a Navy seaman rape a 12-year-old girl in Ginowan. \\
\hline April 1996 & Japanese PM and US Ambassador discuss removal of Futenma. \\
\hline October 2005 & $\begin{array}{l}\text { Foreign Minister Aso and Secretary of State Rice agree to move some } \\
\text { Marines to Guam and to build a new base in Henoko, Okinawa. }\end{array}$ \\
\hline February 2009 & DPJ President Ichiro Ozawa suggests a smaller US military presence. \\
\hline August 2009 & SDP manifesto promises to oppose the Henoko replacement base. \\
\hline August 2009 & DPJ suggests “move in the direction of re-examining” base relocation. \\
\hline December 2009 & Hatoyama refuses to decide a base relocation strategy. \\
\hline January 2010 & Hatoyama promises to name a relocation site by May. \\
\hline May 2010 & Hatoyama announces a lightly revised relocation plan. \\
\hline June 2010 & Hatoyama resigns as prime minister. \\
\hline
\end{tabular}

Nilep, Chad. 2013. "Promising without Speaking: Military Realignment and Political Promising in Japan." In Discourses of War and Peace, Adam Hodges (ed.). Oxford:

Oxford University Press. 
Most unhappy about the government's lightly revised plan was the Social Democratic Party, which actually had campaigned on a promise to oppose relocation within Okinawa. SDP president and the cabinet's Consumer Affairs Minister Mizuho Fukushima threatened to resign from the cabinet over the issue. In order to prevent dissension and possible calls to dissolve the government, Chief Cabinet Secretary Hirofumi Hirano suggested that the cabinet could approve a plan with no specifics, and the prime minister would officially announce the details in a speech to the public, not to parliament (JIJI 2010, May 28a). Such legal manoeuvring did not satisfy Fukushima, however, and when she refused to sign cabinet approval for the agreement Hatoyama dismissed her from the cabinet (JIJI 2010, May 28b). On 2 June, with the SDP joining the Liberal Democratic Party and minor opposition parties in calling for a new government, Hatoyama suddenly and somewhat unexpectedly announced his intention to resign (JIJI 2010, June 2). DPJ Minister of Finance Naoto Kan was elected new Prime Minister on 4 June (Kyodo 2010, June 9).

\section{Discussion}

The Democratic Party of Japan is, in ideological terms, a broad coalition. The party was formed in 1996 as a centrist party and was soon joined by the Japan Socialist Party, who wished to form a stronger rival to the right and center-right Liberal Democratic Party (Christensen 1998). In 1998 the party combined with several smaller centrist or center-left parties, and their own version of history records this as the official beginning of the party (DPJ 2010). Then in 2003 the party was joined by the Liberal Party, a right-leaning party led by former LDP lawmaker Ichiro Ozawa. These parties and factions were united less by political vision or ideology than by a desire to wrest power from the LDP.

Given the broad span of left, right, and center politicians in his party, candidate Hatoyama made few bold and unambiguous promises in this party manifesto or his campaign speeches. After forming a coalition government with the centrist People's New Party and the pacifist left Social Democratic Party, Prime Minister Hatoyama was even more circumspect, often promising to study issues and to come to the best possible conclusion, without giving any clear indication of what he thought those solutions consisted of, and without even framing the problems clearly.

Hatoyama's lack of strong statements or apparent preferences proved problematic in terms of interdiscursive stance-taking. John W. Du Bois defines stance as follows.

Stance is a public act by a social actor, achieved dialogically through overt communicative means, of simultaneously evaluating objects, positioning subjects (self and others), and aligning with other subjects, with respect to any salient dimension of the sociocultural field. (Du Bois 2007: 163)

Michael Lempert (2009) analyzes American politicians' stance-taking across broad discursive fields, beyond any particular communicative event. Lempert is particularly interested in the notions of "conviction" versus "flip-flopping" in US politics, and how judgments about these attributes relate to stance-taking in multiple speech events over time. A politician who evaluates an object differently in front of different audiences may be charged as an untrustworthy and unreliable flip-flopper. 
Hatoyama's personal stance toward military realignment was never clearly or directly stated. His evaluations of various suggestions by members of his coalition and other political actors were not transparently present in Hatoyama's own words, but were construed in analysis and interpretation of his words and actions by the news media and the people. This situation parallels what Lempert calls "addressivity by construal" (2009: 228), in which the stance-taker's alignment with particular addressees is achieved through interpretation by others. Observers projected onto Hatoyama's discourses and stances an evaluation of the advisability of various approaches to Futenma's relocation, an evaluation by construal.

While his lack of clear statements may not have opened Hatoyama to charges of flip-flopping (a charge commonly made in the US) per se, his uncertain stance nonetheless failed to signal conviction (Lempert 2009) or message (Hill 2001). On the issue of the Futenma replacement facility, Hatoyama would later suggest that his personal preference had been to remove the new base to Guam, and that he later concluded that placement in Kagoshima prefecture, Japan, would be a proper compromise (Kyodo 2009, June 11). While in the Prime Minister's Office, though, he did not clearly state these preferences. In the absence of such statements the press, the public, and members of his government were free to project their own views on the "revision" and "re-examining" process called for in the party's manifesto.

Prime Minister Hatoyama's principle failure seems to relate to, in Hill's (2001) terms, the discourse of theater. He failed to project a consistent message, an image of the intellectual conviction and emotional appeal understood as leadership ability. Indeed, as his government's approval ratings fell throughout late 2009 and early 2010, respondents to several public opinion surveys cited Hatoyama's lack of leadership as a reason for their disapproval (Daily Yomiuri 2009, October 29; IHT/Asahi 2009, December 23; Daily Yomiuri 2010, April 7; IHT/Asahi 2010, April 20). It is curious, then, that so many media analyses of the government's failure blamed Hatoyama for failing to keep a promise (e.g. Japan Times 2010, May 7; IHT/Asahi 2010, May 7; Daily Yomiuri 2010, May 16; IHT/Asahi 2010, May 25; The Korea Herald 2010, May 25; JIJI 2010, June 2).

In an editorial published just after he announced his resignation, the Daily Yomiuri concluded that Hatoyama had actually delivered on many of his campaign promises. He introduced subsidies for child care and for agriculture, and made public high schools tuition-free. He also made progress toward creating a promised East Asia diplomatic community and introduced a law to give the cabinet greater power over the bureaucracies (Daily Yomiuri 2010, June 3). The Japan Times suggested that despite his successes, two failures came to define Hatoyama: "his failure to keep his promise to relocate the functions of [Futenma] out of Okinawa Prefecture, and a political funds scandal" (2010, June 3).

\section{Conclusion}

The failure of the Hatoyama government illustrates that in Japan, as in the United States, individual leaders are deemed responsible for certain discourses that surround them. Leaders are judged against two yardsticks: their degree of leadership, including conviction and message communicated in a discourse of theater; and their degree of honesty, expressed in the discourse of truth and measured by the degree of fit between words and actions. 
What this case further illustrates is that, at least in Japan, the individual leader held responsible for these discourses need not have a central role in their creation. During the general election campaign of 2009, Yukio Hatoyama made no clear statements regarding removal of US forces from Okinawa prefecture. Yet given his party's pledge to "Move in the direction of re-examining the realignment of the U.S. military forces in Japan" (DPJ 2009), his coalition partners' stated desire to reduce the burden on the people of Okinawa (Daily Yomiuri 2009, December 4), and a general expectation that a change of government would result in broad policy shifts (IHT/Asahi 2009, October 23; JIJI 2010, June 2), many assumed that he would do so. In the absence of clear statements Hatoyama, as leader of the government, was held accountable for "promises" that did not come primarily from him.

As regimes of personalism (Duranti 1988, 1993) lead participants to think of discourse as a property that flows from an individual, concomitant ideas lead them to think of leadership and political direction in similarly personalist ways. Yet as this case shows, neither the individual politician nor the state is the sole locus of political discourse. Particularly with democratic systems of governance, but also in other forms of society, political will is emergent from the interaction of multiple, diverse individuals. This includes not only the "speaker" of traditional philosophy of language, but also "hearers" in the broader polity.

The lenses of truth and theater described by Hill (2001) apply not only to uptake of actual statements during a campaign, but equally to actions and to the lack of clear statements from campaigns and governments. Actions taken while in office that raise expectations of future change may be taken as promises to act. When a metaphorical promise, an expectation of future action that arises among observers but is not related to any particular communicative act, is not met, the individual implicated in the discourse may still be judged as untrustworthy.

The leadership and honesty of a political actor are judged not only against their own locutions, but also in light of actions taken or statements made by political allies or opponents. In the case described above, Yukio Hatoyama made few direct statements about the US Marine Corps Air Station Futenma realignment plan. But in an atmosphere of great public interest on the issue, Prime Minister Hatoyama was held accountable for statements made by his foreign minister, defense minister, and chief cabinet secretary, as well as campaign positions by his coalition partner the Social Democratic Party. Because his party defeated the Liberal Democratic Party in the general election, Hatoyama was also partly defined as "opposite" to LDP campaign positions. Finally, expectations expressed in the press and held among the electorate were recast as promises by the prime minister and his party. In this environment, Hatoyama was held responsible for a metaphorical promise, expectations of future action arising from a broadly co-constructed discourse. Ultimately Hatoyama was blamed for breaking promises he had only a small role in creating.

As peace is not merely the absence of war, successful political discourse is not merely the absence of divisive or unpopular speech. Political accord arises - or fails to arise - among a broad populace. A would-be political leader needs to find significant accord with the society he or she would lead. As the case of Yukio Hatoyama shows, failure to seek such accord can be a path to loss of position just as surely as failure to deliver one's promises can. Avoiding discord is not a sufficient path to peaceful political engagement. Instead, accord and mutual agreement must be sought through active engagement with individuals and factions throughout society. 


\section{References}

Asahi.com. 2010, May 7. Futenma move 'not a DPJ' promise. The Asahi Shimbun. Retrieved 4 December 2010 from http://www.asahi.com/english/ TKY201005060262.html

Christensen, Ray. 1998. The effects of electoral reforms on campaign practices in Japan. Asian Survey 38(10), 986-1004.

Daily Yomiuri. 2009, June 13. Can SDP compromise with DPJ? Security, international affairs differences could undermine coalition talks.

---. 2009, July 17. DPJ compiles key policies.

---. 2009, September 24. Japan, U.S. must grasp nettle of difficult issues (editorial).

---. 2009, October 14. Futenma move should be within prefecture (editorial).

---. 2009, October 29. Deepen talks on security, financial resources (editorial).

---. 2009, November 3. Hatoyama should realize importance of base issue (editorial).

---. 2009, November 7. Govt must do more for U.S. security alliance (editorial).

---. 2009, November 14. Settle Futenma issue to deepen alliance (editorial).

---. 2009, November 18. Restore U.S. trust by settling relocation issue (editorial).

---. 2009, December 4. Resolve Futenma issu [sic] by year-end (editorial).

---. 2010, January 14. Solve Futenma issue first to deepen Japan-U.S. ties (editorial).

---. 2010, January 30. Hatoyama speech dodged tough issues (editorial).

---. 2010, April 7. Party politics in crisis over rise in floating voters (editorial).

---. 2010, April 15. Deadline looms for Hatoyama (editorial).

---. 2010, May 14. Govt's Futenma plan a hopeless hodge-podge (editorial).

---. 2010, May 15. No one will believe Hatoyama's words (editorial).

---. 2010, June 3. Hatoyama out of power, out of time (editorial).

Democratic Party of Japan [DPJ]. 2009. 2009 Change of Government: The Democratic Party of Japan's Platform for Government. Retrieved 6 July 2010 from http://www.dpj.or.jp/english/manifesto/manifesto2009.pdf

---. 2010. The Democratic Party of Japan (web site). Retrieved 14 December 2010 from http://www.dpj.or.jp/english/about_us/ dpj_profile.html

Du Bois, John W. 2007. The stance triangle. In R. Englebretson (ed.) Stancetaking in Discourse. Amsterdam: John Benjamins, 139-182.

Duranti, Alessandro. 1988. Intentions, language, and social action in a Samoan context. Journal of Pragmatics 12, 13-33.

---. 1993. Intentions, self, and responsibility: an essay in Samoan ethnopragmatics. In J. Hill and J. Irvine (eds.) Responsibility and Evidence in Oral Discourse. Cambridge: Cambridge University Press, 24-47.

Economist. 2010. The new battle of Okinawa. Retrieved 12 December 2010 from http://www.economist.com/node/15271146.

Estévez-Abe, Margarita. 2006. Japan's shift toward a Westminster system. Asian Survey 46(4), 632-651.

Fisch, Arnold G. 1987. Military Government in the Ryukyu Islands, 1945-1950. Army Historical Series. Washington: U.S. Government Printing Office.

Furukawa, Hajime, Takashi Murao and Shuhei Kuromi. 2009. Aso fails to strike in debate with DPJ head. Daily Yomiuri.

Grice, H. Paul. 1975. Logic and conversation. In Peter Cole and J.L. Morgan (eds) Syntax and Semantics 3: Speech Acts. New York: Academic Press, 41-58.

Nilep, Chad. 2013. "Promising without Speaking: Military Realignment and Political Promising in Japan." In Discourses of War and Peace, Adam Hodges (ed.). Oxford:

Oxford University Press. 
Harris, Tobias and Colum Murphy. 2009, July 3. Japan: Can the DPJ bring democracy to Japan? Far Eastern Economic Review.

Hatoyama, Yukio. 2009. A new path for Japan. The New York Times. Retrieved 23 June 2010 from http://www.nytimes.com/2009/08/27/ opinion/27ihtedhatoyama.html

Hill, Jane. 2001. "Read My Article": Ideological complexity and the overdetermination of promising in American presidential politics. In Paul Kroskrity (ed) Regimes of Language: Ideologies, Polities, and Identities. Santa Fe: SAR Press, 259-292.

IHT/Asahi. 2009, July 27. Minshuto on policy (editorial).

---. 2009, October 23. Relocating Futenma base (editorial).

---. 2009, October 27. Hatoyama policy speech (editorial).

---. 2009, December 5. Futenma base dilemna (editorial).

---. 2009, December 23. Honeymoon is over (editorial).

---. 2010, January 11. Okada-Clinton meeting (editorial).

---. 2010, January 26. Nago mayoral election (editorial).

---. 2010, March 6. New Futenma plan (editorial).

---. 2010, April 21. Disenchanted voters (editorial).

---. 2010, May 7. Weak leadership (editorial).

---. 2010, May 15. Futenma impasse (editorial).

---. 2010, May 25. 'New' Futenma plan (editorial).

Inoue, Masamichi. 2007. Okinawa and the U.S. Military: Identity Making in the Age of Globalization. New York: Columbia University Press.

Japan Constitution, Article 9.

Japan Times. 2009, September 6. DPJ and Japan-U.S. relations (editorial).

---. 2009, September 11. Coalition on delicate foundations (editorial).

---. 2009, September 25. Dancing around delicate issues (editorial).

---. 2009, October 23. A base Okinawans can live with (editorial).

---. 2010, January 27. Nago voters speak on Futenma (editorial).

---. 2010, April 24. Shift gears on base relocation (editorial).

---. 2010, May 5. Mr. Hatoyama's rating in a spin (editorial).

---. 2010, May 7. Mr. Hatoyama at an impasse (editorial).

---. 2010, June 3. A disappointing departure (editorial).

JIJI Press English News Service. 2010, May 28a. Hatoyama keeps trying to bridge gap over base issue within coalition.

---. 2010, May 28b. Hatoyama dismisses Fukushima over Futenma relocation policy.

---. 2010, June 2. Update: Japan Prime Minister Hatoyama announces resignation.

Kin, Kwan Weng. 2009, July 3. Opposition leader hit by new scandal. Straits Times.

Korea Herald, The. 2010, May 24. Hatoyama's reversal. Seoul.

Kyodo News. 2009, July 24. SDP urges DPJ, PNP to work together to legislate nonnuclear principles.

---. 2009, October 2. LEAD: Cabinet members to continue talks on Futemma relocation.

---. 2009, October 3a. LEAD: New candidate site necessary to move U.S. base facility: Maehara.

---. 2009, October 3b. Okada positive about reviewing Futemma relocation plan. Siem Reap, Cambodia.

---. 2009, October 7. 2ND LD: Hatoyama hints at possible change of stance on Futemma relocation. 
---. 2010, January 30. Full text of Prime Minister Hatoyama's policy speech in Diet. Part 9.

---. 2010, June 9. 3RD LD: Cabinet's support rate surges to 62\% under new PM Kan.

---. 2010, June 11. Hatoyama regrets short deadline to resolve Futenma issue.

Lempert, Michael. 2009. On 'flip-flopping': Branded stance taking in U.S. electoral politics. Journal of Sociolinguistics 13(2), 223-248.

Liberal Democratic Party [LDP]. 2009. Liberal Democratic Party: The Ability and Strength to be Responsible for Protecting Japan. Retrieved 6 July 2010 from http://www.jimin.jp/jimin/english/pdf/2009_yakusoku_e.pdf

Maeki, Riichiro. 2009, October 8. POLITICAL PULSE: DPJ shouldn't be so stubborn: Blind adherence to campaign promises could harm public. Daily Yomiuri.

Ministry of Foreign Affairs [MOFA]. 2006. United States-Japan Roadmap for Realignment Implementation. Retrieved 23 June 2010 from http://www.mofa.go.jp/region/n-america/us/security/scc/doc0605.html

Ministry of Defense. 2006. 日米安全保障体制の強化 [Strengthening the JapaneseAmerican system to guarantee security]. Retrieved 12 December 2010 from http://www.clearing.mod.go.jp/hakusho_data/2006/2006/html/14262000.html

Nichols, Charles S., and Henry Shaw. 1955. Okinawa: Victory in the Pacific. Historical Section, Headquarters US Marine Corpss. Retrieved 20 December 2010 from http://www.ibiblio.org/hyperwar/USMC/USMC-MOkinawa/index.html.

Okinawa Times. 2009. [鳩山「普天間」発言] 公約実現へ毅然とせよ. [Hatoyama’s Futenma speech: Resolve to keep your promise].

Rosaldo, Michelle. 1982. The things we do with words: Ilongot speech acts and speech act theory in philosophy. Language in Society 11(2), 203-237.

Safire, William. 1988, September 4. On language: Read my lips. The New York Times. Magazine section.

Searle, John. 1975. A taxonomy of illocutionary acts. In K. Gunderson (ed.) Language, Mind, and Knowledge. Minneapolis: University of Minnesota Press, 344-369.

---. 1980. Speech Acts: An Essay in the Philosophy of Language. Cambridge: Cambridge University Press.

Social Democratic Party [SDP]. 2009. 衆議院選挙公約 2009 . 概要版. [2009 Lower House election manifesto. Digest edition.] Retrieved 25 January 2011 from http://www5.sdp.or.jp/policy/policy/election/manifesto02_01.htm.

Treaty of mutual cooperation and security, with agreed minute and exchanges of notes. 1960. Japan-United States. TIAS 4509.

Treaty of peace with Japan. 1952. Multilateral. TIAS 2490.

Nilep, Chad. 2013. "Promising without Speaking: Military Realignment and Political Promising in Japan." In Discourses of War and Peace, Adam Hodges (ed.). Oxford:

Oxford University Press. 